\title{
Big Data Application in Commercial Economy Management
}

\author{
Wang Xiaodi, Zhang Yuan, Zhang Xiaojing, Xue Li \\ Beijing Institute of Science and Technology \\ Beijing, China \\ wangxd@bjstinfo.com.cn
}

\begin{abstract}
In the era of information technology development, big data is playing an enormous role in commercial development circle, cybereconomy new challenges for enterprise development and competition, and gradually become a significant management model in commercial economic management. Furthermore, commercial big data has initiated a new round of industrial revolution and played a positive role in economic governance, which is an important application in national basic database construction, e-government, internet banking, and ecommerce and enterprise information management. Firstly, this paper briefly introduced big data promoting function and industry application. Secondly, authors discussed commercial big data issues in actual application process, and function and commercial opportunity in business management. Finally, authors pointed out big data usage opportunities and challenges, proposed suggestions for promoting social and economy growth.
\end{abstract}

Keywords-Big data; Commerce; Economic management; Application

\section{INTRODUCTION}

In the context of economic development integration, knowledge economy era is an information resources era; informatization construction becomes rolling full steam ahead. Informatization comprises government informatization, enterprise informatization and social informatization. Big data has become a new hotspot of information technology and a new direction of industrial development. It has brought profound changes in economic and social development. The premier global market intelligence firm, International Data Corporation (IDC), analyzed China will be the biggest big data market in the world. Big data application has aroused extensive attention, and it is an important issue to fully exploit big data value to promote economic and social development innovation.

\section{BIG DATA AND ITS VALUE}

In 2008, "Nature" publication issued "Big Data", based on research status of several disciplines, systematically introduced and analyzed the potential value and challenges contained in big data. Big data concept gradually evolved into information knowledge data, which could translate into business intelligent activities advantages. Big data is a valuable resource to promote economic and social development, and big data collection and application is becoming a significant means for countries fight for information society control power.

Big data refers to a term for data sets that are so large or complex, and unable to process and manage data resources with regular software tools within a reasonable time. Challenges include capture, storage, analysis, data curation, search, sharing, transfer, visualization, querying, and updating and information privacy [1]. The characteristics of big data, a large amount of data (Volume), fast aging treatment (Velocity) strong multielement and diversity (Variety), powerful potential value (Value); it mainly includes government affairs data, industry data, and social data. In the era of knowledge economy, data are valuable assets, wealth resources and engine innovation driven in economic and social development. Because of great leap forward development of massive information resources obtaining technology, internet transmission technology, data storage and processing technology and so on leaps and bounds development, big data has become science and technology information technology development priorities. (Figure 1)

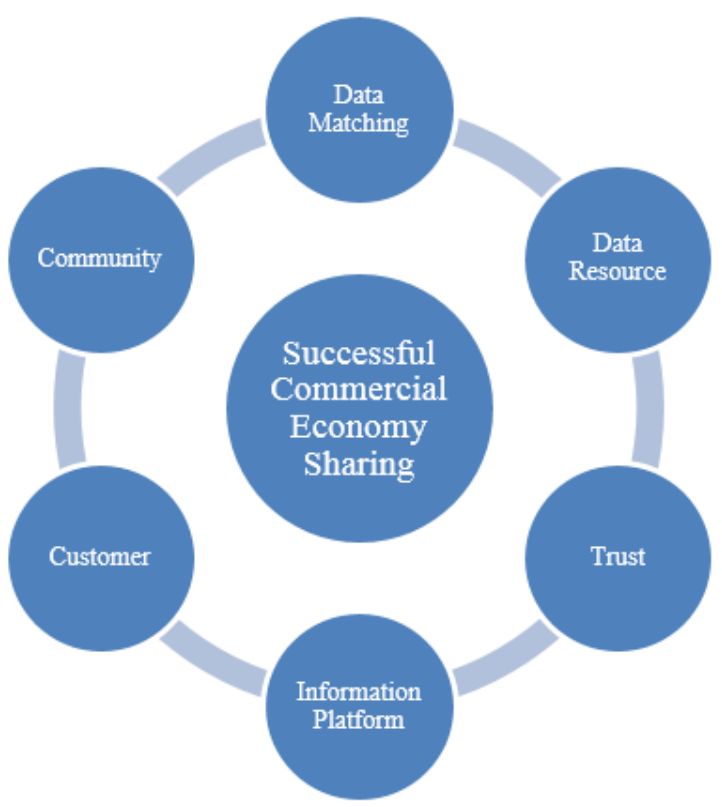

Fig. 1. Successful Commercial Economy Sharing 


\section{BIG DATA IN CHINA'S INDUSTRY APPLICATIONS}

With popularization of Internet technology and its application, economic and social informatization leads data growing faster and more abundant. At present, big data is mainly used in the following aspects in China:

\section{A. National basic database and information transaction processing}

China has built a national population database covering 1 billion 300 million people, and it has provided household registration and management services. Moreover, it established integrated business entity database, spatial geography database and statistical information database [2].

With regard to macroeconomic regulation and control, market supervision, social management and announcement service, China's government has promoted departmental information sharing and business collaboration, expanded application fields and enhanced efficiency administration and service level. For instance, the State Administration of Taxation, the People's Bank of China and the Ministry of public security and the Ministry of Finance, have taken advantage of basic information data development application service start over demonstrating project demonstrating project and application promotion.

\section{B. E-government business collaboration}

E-government departments' business collaboration is to carry out data exchange by distributing the basic database on different departments, so as to achieve interdepartmental collaboration and supervising association. For example, Fujian provincial government information sharing platform, integration thirteen agricultural related business sector information resources, to carry out agriculture information integrated services; Province government has launched a collaborative editing and business wage salaries issuing administrative database, enterprise personnel pension insurance cooperative service.

\section{New-type urbanization construction support}

Past data mining work has mainly mined commercial value of structural data mining, it not only screened semi-structured and unstructured business information, but also shield of big data continuous generation information. Thus, it has been unable to adapt modern enterprise development demand. With urban acceleration, there has enormous demand of geospatial information resources, such as high-resolution satellite remote sensing data, aerial photography, and remote sensing information; furthermore, there are different scales of topographic maps, land-use maps, architectural maps and road maps. On this basis, government built government administration, household register, community, vehicle, construction, environmental protection, social security, transportation and disaster information database.

\section{Logistics public information service}

Modern logistics industry development requires multisource, massive, spatio-temporal data resources, data integration processing, value-added information mining, and internet of things, cloud computing, mobile communications, digital earth and other technical support.

Logistics public information services mainly include: realizing information sharing and networking electronic operation on network information platform; providing internet of things information and value-added services for transportation supply and demand sides, such as logistics information communication, qualification certification, logistics, finance, transportation distribution and supervision; providing logistics space information service, such as logistics customer positioning, facilities location and vehicle configuration.

\section{E. Internet Finance}

The traditional real economy financial service mode has mainly matched capital supply and demand matching by two kinds of intermediary services. One is indirect finance baking model, which provides financial debit and credit to consumers through depositors collect funds; on the other hand, it is direct financing model, which develops financial services through stock and bond markets. Internet financial model, using mobile payments, social networking and search engines, issuing and trading loans, stocks and bonds online will have a fundamental impact on financial model.

\section{F. E-commerce and enterprise information management}

Application and promotion of internet e-commerce focuses on discovery, excavation and business recommendation for customers personalized information. Research shows that $84 \%$ of world's customers believe in good reputation and highly valued business information from friends and family. In addition, E-commerce platform for customer online browsing, consumer behavior collection and analysis can help to understand customer spending intentions, achieve customer demand advertising investment and transactions.

\section{BIG DATA IN COMMERCIAL AND ECONOMIC MANAGEMENT}

\section{A. Increasing scientific business decisions}

Enterprises use big data for operating management, and gradually make quantitative data become a major reference factor for enterprise decision-making. Furthermore, most enterprises adopt business operation and management decision by analytical data. By integrating data between various departments and strategic decision, the firm can effectively increase scientific and feasibility business decision [3].

\section{B. Generating capital value}

Big data industry applications constantly enhance corecompetitiveness, but also make enterprises to strengthen customer feedback and customer service. Attaching importance to customer personalized needs and suggestions and conducting a comprehensive customer analysis, enterprise value chain has been continuously strengthened, so as to create greater economic benefits. In addition, according to analyzing customer data, enterprise can advance data efficiency and accuracy, make different marketing strategies 
for different customer groups, encourage enterprises to gradually occupy greater market share.

\section{Strengthening enterprise data mining}

During the past data mining work, mainly mining commercial value structural data, it not only shielded semistructured and unstructured business information structure, but also screened big data information production, it has been unable to adapt to modern enterprise development needs. With emerging in a new generation data mining tools, enterprises have been forced to constantly advance data mining program, so that they can process various data requirements. Users could discover various patterns in big data, and understand data contents and sources, and also assist enterprises to make scientific and reasonable developing forecasts.

\section{Enhancing enterprise data technology team}

Big data requires ability to observe strong implementation data and technical specialists to support who can process big data efficiently. Therefore, enterprises will introduce experienced digital technical personnel to strengthen industry data technology, reflect enterprise potential commercial value; it will provide significant reference for enterprise management and management decision. (Figure 2)

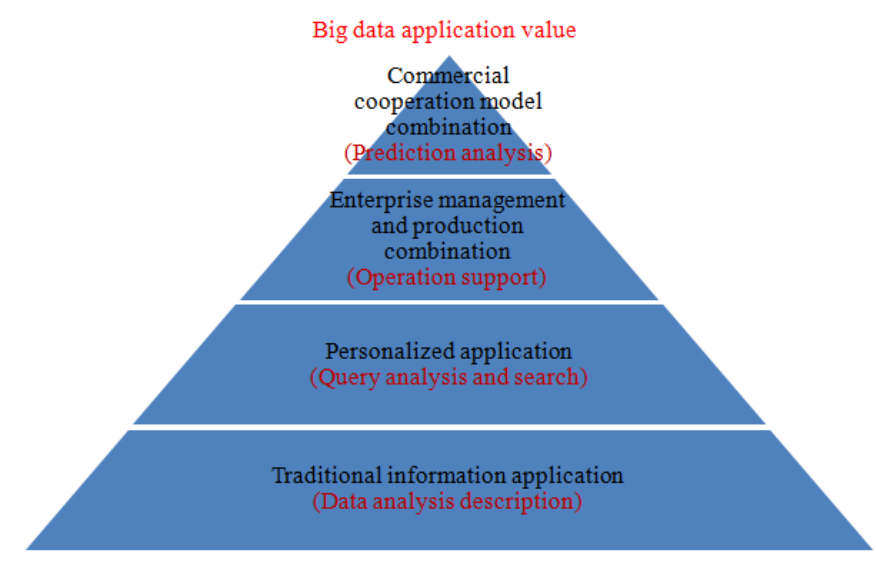

Fig. 2. General view of big data and social economy management relationship

\section{BIG DATA ISSUES IN ECONOMIC AND SOCIAL DEVELOPMENT}

In the social and economic situation of increasingly fierce competition, traditional commercial economic management model has been unable to satisfy industry development. Consequently, modern enterprise should dig huge potential business opportunities in commercial data to create development space. However, big data still has many issues in modern economic society, which influences its utility [4].

\section{A. Data reliability decline}

In most cases, commercial data represents real business situation. Especially in big data era, false information emerges in large number and hides in a variety of data stream; besides, this will reduce data reliability, and it is difficult to accurately judge true and false data to make wrong decisions and judgments.

\section{B. Data security risk}

Data security is one of the important issues for huge data storage. Due to big data relates development and commercial trade secrets, which caused a high attention to hackers, Trojan Horse, and viruses data security risks. Thus, it will lead to enterprise secrets and customer personal information illegal use and leakage which resulting in significant economic loss and huge compensation.

\section{Data privacy issues}

As big data commercial value has been dug widely, it has led data privacy emerging. Many website companies exploit had been broken browser privacy settings, tracked online user situation and sent various advertisements. It had intensified data trust and privacy protection issue, while made data security becomes key issue concern.

\section{POLICY RECOMMENDATIONS FOR BIG DATA APPLICATIONS TO PROMOTE ECONOMIC INNOVATION}

Big data applications promote the innovation of social and economic development, we should attach great importance to big data strategy, we should grasp key fields and core data development, persevere in "data, technology and application" development strategy [5].

\section{A. Formulating big data development strategy}

Big data has penetrated into various society fields, such as economy, healthcare, housing, transportation and education. It has affected enterprises decision-making and national development strategy. As a result, big data has elevated into national strategies in worldwide. In 2012, US government launched the "Big Data Research and Development Plan" national strategy, announced big data investment fields. UK, France and other developed countries have introduced policies to develop big data technology. Our country should formulate big data national level development strategy. Making top-level design, guide and drive in development goals, development principles and key technologies, it is aim to advance big data development and application in various fields and industry.

\section{B. Building big data integrated information platform}

Big data integrated information platform is using big data to innovate economic and social development, and it affects data resource collection, analyzing, mining and application in hardware facilities, data publicity, information processing. Construction integration and national information construction, can lead technology oriented enterprises and public participation as main force to achieve unified storage in all fields. Through data resources sharing and application, information monopoly between government departments has been broken, which has led to data-driven normalization of economic and social development. 


\section{Promoting big data demonstration applications}

Firstly, government should strengthen data collection management, pay attention to incorporate economic data, management data, public opinion data and environmental data. Secondly, we must advance data quality management, and collecting data methods should be scientific transparency without human interference. Finally, government requires big data safety management enhancing, big data collection may involve national information security and citizen privacy. Government should formulate big data technical standard and operation specification, pay attention to big data construction safety system, and strengthen supervision of sensitive data.

\section{Strengthening big data resources management}

China's government can focus on improving public livelihood and urban governance, actively promote big data integration and application of environment protection, health care, education and transportation to improve government decision-making, government forecasting ability, public service efficiency and operation cost reduction.

\section{E. Optimizing big data development environment}

Utilizing big data application to innovate economic and social development requires a fine environment and government support and investment. Firstly, we should increase government investment in big data industry, support key enterprises in data items implementation, implement tax incentives in data processing service, and give financial support for key technology research and development. Secondly, we should actively innovate financial products and services, support big data achievement transformation and industrialization, encourage and guide private and foreign capital to enter big data field; government should establish investment guidance and investment financing system by social funding. Thirdly, government should improve big data intellectual property protection system, facilitate data sharing and integration. Furthermore, we should promote data source traceability, security refinement and data value creation. Finally, government should consummate relevant laws and regulations, define legal norms for data collection, and promote data sharing, so as to strengthen citizens' individual privacy and enterprise business trade protection.

\section{CONCLUSION}

Big data is the new era product, which not only affects public daily life, but also influences commercial development. Maximum value of big data is to improve social productive forces by data, and it will be new growth point of future cultivation and mining field to promote economic development, entrepreneurship innovation, and digital economy development strategy [6]. Therefore, we should focus on big data potential issue research in commercial economy management, and actively explore big data application in business and economic development, in order to discover big data commercial value and enhance comprehensive utilization to create greater enterprise economic value.

\section{REFERENCES}

[1] Big data (Wiki): https://en.wikipedia.org/wiki/Big_data.

[2] José María Cavanillas, Edward Curry, Wolfgang Wahlster. New Horizons for a Data-Driven Economy: A Roadmap for Usage and Exploitation of Big Data in Europe[H]. 2016(2):65-78.

[3] Liping Yu. Big Data and Big Data Economics[J]. China Soft Science, 2013 (7). (In Chinese)

[4] Feng Lou. Big data and Economics: characteristics, principles, implications, and the future. China Collective Economy[J]. China Collective Economy, 2016 (7). (In Chinese)

[5] Zhuning Li. Big data influence on Economics. Economic \& Trade, 2017(6). (In Chinese)

[6] Viktor Mayer-Schönberger. Big Data A Revolution[H].2014(4). 